\title{
Performance of Oats Genotypes for Fodder and Grain Yield under Cold Arid Conditions of Leh, Ladakh
}

\author{
Yogesh Kumar, T.H. Masoodi, Kaneez Fatima, S.A. Ganie , F.A. Bahar, \\ Ajaz A. Lone, M.I. Makhdoomi and Phuntsog Tundup \\ Department of Plant Pathology, High Mountain Arid Agriculture Research Institute Leh \\ Ladakh, SKUAST-K, India \\ *Corresponding author
}

\begin{abstract}
A B S T R A C T
Keywords

Genotypes, Sabzar,

Fodder, Oat and yield

Article Info

Accepted:

10 October 2018

Available Online:

10 November 2018

To find the performance of Oat Genotypes for fodder yield under Ladakh conditions, the research was conducted at High Mountain Arid Agriculture Research Institute, Leh SKUAST- KASHMIR during kharif season 2017-2018.The experiment consists of six genotypes including check (SKO-90, JHO-851, JHO-996, SKO-108, SKO-20 and Sabzar) laid in Randomized Block Design (RBD) with three replications. The plot size of $2 \times 2$ meter was used in this experiment. These high yielding varieties of fodder suitable for cold arid region of Ladakh shall be of great significance to the local farmers for livestock. Among all the genotypes Sabzar showed maximum fodder yield $(6053 \mathrm{~kg} / \mathrm{ha})$ followed by SKO-20 $(5093 \mathrm{~kg})$ as compared to other genotypes tested during the present experiment.
\end{abstract}

\section{Introduction}

Forages are the mainstay of animal wealth and their production is the backbone of livestock industry. The scarcity of green forages and grazing resources in the country has made the livestock to suffer continuously with malnutrition resulting in their production potentiality at sub optimum level as compared to developed nations. India is having the largest livestock population of $520 \mathrm{~m}$ heads which is about 15 per cent of the world's livestock. India supports 55 per cent of world's buffaloes, 16 per cent of the world's cattle, 20 per cent of the world's goats and 4 per cent world's sheep population but is having only 4.4 per cent of the cultivated area under fodder crops with an annual total forage production of $833 \mathrm{~m} \mathrm{t}(390 \mathrm{~m} \mathrm{t}$ green and 443 $\mathrm{m} t$ dry), whereas, the annual forage requirement is $1594 \mathrm{~m} \mathrm{t}(1025 \mathrm{~m} \mathrm{t}$ green and $569 \mathrm{~m} \mathrm{t}$ dry) to support the existing livestock population. The present feed and fodder resources of the country can meet only 48 per cent of the requirement with a vast deficit of 61.1 per cent and 21.9 per cent of green and dry fodder, respectively (Anonymous, 2009).

Oats (Avena sativa $\mathrm{L}$ ) is one of the most important kharif cereal fodder crop grown in summer throughout Leh, Ladakh region both under irrigated and rainfed conditions. A distributed rainfall of below $100 \mathrm{~mm}$ and an optimum temperature range of $30-32^{\circ} \mathrm{C}$ during 
the four months duration is sufficient to meet its requirement as a fodder crop. It is a quick growing, palatable, succulent and nutritious fodder crop. The oat is a multicut fodder, which can play a pivotal role in establishing a more productive dairy industry in the region. The improved varieties of oats produce threefold green fodder i.e. 40-60 tones per hectare and can feed double number of animals per unit area as against the traditional fodder crops. The oat varieties have already been developed possessing characteristic i.e. early to late duration, high yielding, more nutritious, palatable, multicut and disease free varieties for various agro-ecological zones. Studies on characterization and evaluation of one and two-harvest of oats in oats have been carried out earlier by Arora and Jhorar (2007) and Arora (2013) whereas, Arora et al., (2009) made an assessment of fodder production potential of oat varietal trials under single cut system over the seasons. Arora and Jhorar (2005) and Jhorar et al., (2009) evaluated the fodder production potential in multi-cut oats. Oat is a cold and drought tolerant crop and it provide green fodder during the lean period (May to August) when green fodder is scarce and animals are fed with dry fodder.

Genotype x environment interaction remained always a serious problem in crop production while recommending a variety for some region/area. Environment for commercial cultivation cannot be changed but genotype can be modified by hybridization and bio-tech methods to suit to available soil and climate related environmental conditions. For this purpose, breeders are always collecting and creating genetic variability in crops for development of varieties suitable for diverse agro-climatic zones. One cultivar cannot be grown all over the country having multitude of environments. Crop outcome is a product of the genotype and the environment in which crop has been grown. Ideal variety is always one, which possesses general adaptation with higher yield potential (Finlay \& Wilkinson, 1963). No systematic research work appears to have been conducted on oat for its utility as a fodder crop in India but the results of Dhumale and Mishro (1979) shown that fresh fodder yields were positively correlated with plant height, leaf area and number of tillers/plant. This study was aimed to introduce the oat as a green fodder crop among the farmers of Ladakh region.

\section{Materials and Methods}

A field experiment on performance of six oat varieties was conducted under the irrigated conditions at High Mountain Arid Agriculture Research Institute, Leh during the year 2017. Varieties included in the study were SKO-20, SKO-90, SKO-108, JHO-996, JHO-851 and Sabzar. The experiment was laid out in a Randomized Block Design (RBD) with three replications using a plot size $2 \times 2 \mathrm{~m}$. Fertilizers at the rate of 50-50 kg NP ha-1 were applied. Whole phosphorus and half nitrogen were applied at the time of seed bed preparation in the form of di-ammonium phosphate (DAP) and urea, respectively. Whereas, remaining half of nitrogen was applied at the time of first irrigation. Ten plants were selected at random from each plot to record individual plant observation viz. plant height, number of tillers per plant, green fodder yield. Cutting from each plot was taken after 70 days of planting. The samples were weighed to calculate fodder yield on the basis of total green fodder yield per plot for each cultivar. The data collected were analyzed statistically by Fisher's analysis of variance technique.

\section{Results and Discussion}

The data on various parameters recorded in the study have been presented in Table 1 . Plant height data indicated that there were significant differences in plant height among all oat varieties. 
Table.1 Performance of six oat genotypes for fodder yield contributing traits

\begin{tabular}{|l|l|c|c|c|}
\hline S. No & Variety/Genotypes & Plant Height $(\mathbf{c m})$ & Number of Tillers & Fodder Yield $\left(\mathrm{Kg} \mathrm{h}^{-\mathbf{1}}\right)$ \\
\hline $\mathbf{1}$ & SKO-90 & 90.66 & 4.33 & 4070 \\
\hline $\mathbf{2}$ & JHO-851 & 82.66 & 5.66 & 4026 \\
\hline $\mathbf{3}$ & JHO-996 & 96.00 & 4.33 & 4043 \\
\hline $\mathbf{4}$ & SKO-108 & 92.66 & 6.00 & 5080 \\
\hline $\mathbf{5}$ & SKO-20 & 108.00 & 5.66 & 5093 \\
\hline $\mathbf{6}$ & Sabzar (Check) & 118.33 & 8.66 & 6053 \\
\hline $\mathbf{7}$ & C.D & $\mathbf{8 . 7 0}$ & $\mathbf{0 . 6 2}$ & $\mathbf{0 . 9 2}$ \\
\hline $\mathbf{8}$ & C.V & $\mathbf{5 . 3 2}$ & $\mathbf{8 . 9 3}$ & $\mathbf{9 . 5 6}$ \\
\hline
\end{tabular}

Table.2 Performance of different oat varieties for grain yield under the cold arid conditions of Leh, Ladakh

\begin{tabular}{|c|c|c|}
\hline S. No. & Variety/ Genotype & Seed Yield $\mathrm{kg} \mathrm{ha}^{-}$ \\
\hline 1 & SKO-90 & 1216.6 \\
\hline 2 & JHO-851 & 1123.3 \\
\hline 3 & JHO-996 & 1233.3 \\
\hline 4 & SKO-108 & 1126.6 \\
\hline 5 & SKO-20 & 1276.6 \\
\hline 6 & Sabzar (Check) & 1366.6 \\
\hline CD & 37.71 & \\
\hline $\mathrm{CV}$ & 1.67 & \\
\hline
\end{tabular}

Maximum plant height $(118.33 \mathrm{~cm})$ was observed in variety Sabzar followed by SKO$20(108.00 \mathrm{~cm})$. Variety JHO-851 showed the minimum plant height $(82.66 \mathrm{~cm})$. There were significant differences among the number of tillers per plant of different genotypes. Highest number (8.66) of tillers per plant was found in Sabzar followed by SKO-108 (6.00). Varieties SKO-20 and JHO-851 produced 5.66 tillers per plant. Lowest number (4.33) of tillers per plant was observed in JHO-996 and SKO-90. Number of tillers per plant plays a vital role in enhancing the green fodder yield. The present research indicated that among 6 oat varieties, Sabzar was superior than other varieties by producing taller plants and more number of tillers per plant. There were significant differences in fodder yields of six different oat varieties. Maximum fodder yield $\left(6053 \mathrm{~kg} \mathrm{ha}^{-1}\right)$ was produced by the variety
Sabzar followed by SKO-20 which gave 5093 $\mathrm{kg} \mathrm{ha}^{-1}$ but these were statistically at par with variety SKO-108.Minimum fodder yield 4026 $\mathrm{kg}$ ha-1 was observer in variety JHO-851. Performance of different oat varieties under the cold arid conditions of Leh, Ladakh showed that Sabzar is the best variety among six genotypes tested. These results are in conformity with Bhatti et al., (1992) who showed that among 12 oat cultivars, PD2LV65 and Sargodha-81 were found superior than other cultivars by producing taller plants, more tillers/plant and leaf area. So, their results indicated that the cultivars PD2, LV65 and Sargodha 81 produced 28.05 and $26.24 \%$ more green fodder yield and $26.30 \%$ and $21.93 \%$ more dry matter yield, respectively as compared with check variety. Solanki (1977) reported that the new cultivar 'HFO-114' is excellent significantly both in green fodder 
and dry matter yields in single as well as multicut trials than the check varieties Weston-11 and FOS-1/29. Toxler et al., (1980) reported that oats when grown as a fodder crop, cultivar 'Borrus' yield 26 and $60 \%$ more dry matter when grown alone and in a mixture, respectively. Reddy and Rai (1977), Khabkapur et al., (1979), Riveland et al., (1977), Chaudhary (1983) and Chaudhary et al., (1985) have evaluated the suitability of oats as a forage crop under different agroclimatic conditions.

All six varieties of oats showed significant difference in grain yield (Table 2). Maximum grain yield was observed in variety Sabzar (1366.6 kg ha ${ }^{-1}$ ) followed by SKO-20 (1276.6 $\mathrm{kg} \mathrm{ha}^{-1}$ ) and JHO-996 (1233.3 kg ha-1). The least grain yield was observed in variety $\mathrm{JHO}$ $851\left(1123.3 \mathrm{~kg} \mathrm{ha}^{-1}\right)$. These results are also confirmed by Finlay and Wilkinson (1963), who reported that yield of cultivars is influenced by adaptability.

\section{References}

Anonymous. 2009. Post-harvest management of crop residues/grasses/fodder crops and their value addition for sustaining livestock. Winter School, Indian Grassland and Fodder Research Institute, Jhansi, pp. 13-23.

Arora, R. N. 2013. Characterization and evaluation of one and two-harvest of oats. Forage Res., 39 (2): 59-63.

Arora, R.N. and Jhorar, B.S. 2005. Preliminary studies on 2-cuts vs. 3-cuts oats. National Symposium on "Advances in Forage Research and Sustainable Animal Production" August 29-30, 2005, CCS HAU, Hisar. Pp. 37.

Arora, R.N. and Jhorar, B.S. 2007. Evaluation and characterization of oats germplasm for fodder traits under single cut and two cut systems. Paper presented by the senior author at the "National
Symposium: A New Vista to Forage Crops" held from 10-11, Sept. 2007 at BCKV, Kalyani. Pp. 4.

Arora, R.N., B.S. Jhorar, D.S. Phogat, and Bisht, S.S. 2009. An assessment of fodder production potential of oat varietal trials under single cut system over years. Abstracted in "Forage Symposium-2009: Emerging trends in forage research and livestock production" held from 16-17, Feb. 2009 at CAZRI, RRS Jaisalmer, Rajasthan. Pp. 24.

Bhatti, M.B., A. Hussain and Muhammad D. 1992. Fodder production potential of different oat cultivars under two cut system. Pakistan J. Agric. Res., 13: 184-90.

Chaudhary, M.H. 1983. Developments in fodder production in Punjab. Progressive Farming, 3: 22-5.

Chaudhary, M.H., M.A. Mukhtar and Saleem M. 1985. Research in fodder crops in Punjab. Progressive Farming, 5: 28-34.

Dhumale, D.N. and Mishra S.N. 1979. Character association between forage yield and its components in oats. Indian J. Agric. Sci., 49: 918-24.

Finaly, K.W. and Wilkinson G.N. 1963. The analysis of adaptation in a plant breeding programme. Australian J. Agric. Res., 14: 742-54.

Jhorar, B.S., R.N. Arora, D.S. Phogat and Bisht, S.S. 2009. Evaluation of fodder production potential in multi-cut oats. Paper presented and abstracted in "Forage Symposium-2009: Emerging trends in forage research and livestock production" held from 16-17, Feb. 2009 at CAZRI, RRS Jaisalmer, Rajasthan. Pp. 20.

Khabkapur, M.D., V.B. Nodaguda, S. Prithwiraj and Biradar B.M.1979. Preliminary studies on the performance and yield components of oats (Avena sativa L.) Curr. Res., 8: 12. 
Reddy, B.N. and Rai, S.D. 1977. Components of seed yield in oats (Avena sativa L.). Forage. Res., 3: 153-6.

Riveland, N.R., D.O. Erickson and. French E.W. 1977. An evaluation of oat varieties for forage. North Dakota Farm Res., 35: 19-22.

Solanki, K.R. 1977. Improvement of oats for yield and quality. Indian J. Pl. Breed., 37: $230-4$.
Toxler, J., J.F. Colland, J. Lehmann, and F. Weilenamnn 1980. Borrus an oat variety for grain production and as fodder catch crop. Borus, eine Hafersorte Zur Korner-Pro-duktion und fur den Zwischenfuttrban. Mitteilungen for die schweizerische Landwirtschat, 28: $96-100$.

\section{How to cite this article:}

Yogesh Kumar, T.H. Masoodi, Kaneez Fatima, S.A. Ganie, F.A. Bahar, Ajaz A. Lone, M.I. Makhdoomi and Phuntsog Tundup. 2018. Performance of Oats Genotypes for Fodder and Grain Yield under Cold Arid Conditions of Leh, Ladakh. Int.J.Curr.Microbiol.App.Sci. 7(11): 1057-1061. doi: https://doi.org/10.20546/ijcmas.2018.711.122 